\begin{tabular}{|c|c|c|c|c|c|c|}
\hline \multirow{4}{*}{ Impact Factor: } & ISRA (India) & $=3.117$ & SIS (USA) & $=0.912$ & ICV (Poland) & $=6.630$ \\
\hline & ISI (Dubai, UAE & $=0.829$ & РИНЦ (Russia) & $=0.156$ & PIF (India) & $=1.940$ \\
\hline & GIF (Australia) & $=0.564$ & ESJI (KZ) & $=8.716$ & IBI (India) & $=4.260$ \\
\hline & JIF & $=1.500$ & SJIF (Morocco) & $=5.667$ & OAJI (USA) & $=0.350$ \\
\hline
\end{tabular}

\section{SOI: 1.1/TAS DOI: 10.15863/TAS International Scientific Journal Theoretical \& Applied Science}

\author{
p-ISSN: 2308-4944 (print) e-ISSN: 2409-0085 (online) \\ Year: $2019 \quad$ Issue: $06 \quad$ Volume: 74
}

Published: $30.06 .2019 \quad$ http://T-Science.org
QR - Issue

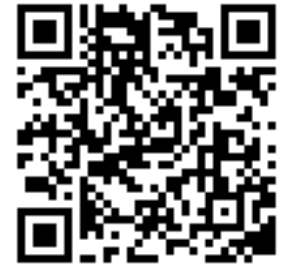

Alaa Hussein Tamadhur University of Kufa

Department of Physics, Faculty of Science, Najaf, Iraq

Hamza Hussain Hayder University of Kufa

Department of Physics, Faculty of Science, Najaf, Iraq hayder.alshibana@uokufa.edu.iq

\title{
THEORETICAL STUDY OF STRUCTURE PROPERTIES OF PRISTINE AND DOPED (AL-N) NANOLAYER AS CS GAS SENSOR
}

\begin{abstract}
Using density functional theory (DFT) with Perdew, Burke, and Ernzerhof (PBE) /6-31G basis set, is investigated the sensitivity of pristine aluminium nitride $\boldsymbol{P}(A l-N)$ nan ribbons, and one atom doped, boron- (B-doped aluminium nitride), (p-doped aluminium nitride) and (c-doped aluminium nitride), for common gases Rn, $K$ and $C s$ ,Gaussian 09 program which applies .

The results show that the adsorptions of of $C$ s on pristine aluminium nitride $\boldsymbol{P}(A l-N)$ (on atom and center ring) are weak physisorption with a $E_{\text {ad }}(0.976,0.987) \mathrm{eV}$, otherwise pristine aluminium nitride $\boldsymbol{P}(A l-N)($ on atom and center ring) could be a good sensor for Sc. However, the adsorptions of Sc, the (B-doped aluminium nitride), ( $p$ doped aluminium nitride) and (c-doped aluminium nitride) (on atom and center ring) are a strong chemisorption with $E_{a d}$ larger than $1 \mathrm{eV}$, due to the strong interaction, (B-doped aluminium nitride), ( $p$-doped aluminium nitride) (c-doped aluminium nitride), (on atom and center ring) could catalyst or activate, suggesting the possibility of as a catalyst. The results reveal the electronic properties of which pristine aluminium nitride modified by boron or carbon and phosphorous doping and molecules adsorption, that could be used to design chemical sensors, and pristine aluminium nitride $\boldsymbol{P}(A l-N)$ could be used to build sensors for the detection of particular molecules in this research.

Key words: pristine aluminium nitride, gas adsorption, density functional theory, HOMO and LUMO.

Language: English

Citation: Tamadhur, A. H., \& Hayder, H. H. (2019). Theoretical Study of Structure Properties of pristine and doped (Al-N) Nanolayer as CS Gas Sensor. ISJ Theoretical \& Applied Science, 06 (74), 623-628.

Soi: http://s-o-i.org/1.1/TAS-06-74-76 Doi: crosef https://dx.doi.org/10.15863/TAS.2019.06.74.76
\end{abstract}

\section{Introduction}

The nanostructural properties of Aluminum nitride (AI-N) have been exceedingly synthesized for experimental and theoretical studies due to their broad applications in optics, electronics, and photoelectronics $[1,2]$. The theoretical studies on the molecular adsorption of gases on the Al-N nanosheet surface have been reported recently [3,4] and shown an armchair-shaped edges (Al-N)NRs. These edges have presented semiconducting and nonmagnetic properties, where the direct band gap of ( Al-N)NR decreases monotonically with increasing nanoribbon width [5]. Gases such as $\mathrm{CO}_{2}, \mathrm{k}, \mathrm{Cs}, \mathrm{Rn}, \mathrm{NH}_{3}$, and $\mathrm{O}_{2}$ are examples used for the adsorption on the AI-N surface. For example, the interactions of $\mathrm{CO}_{2}$ on the surface of Al-N nanostructures are investigated to be a candidate $\mathrm{CO}_{2}$ capture material [3]. Also, the adsorption of $\mathrm{NH}_{3}$ and $\mathrm{NO}_{2}$ molecules on the surface of Al-N nanosheets have revealed more interesting results, where the electrical conductivity increases upon the $\mathrm{NO}_{2}$ adsorption, however it becomes insensitive toward the $\mathrm{NH}_{3}$ adsorption [6].

Further details, and to compare between AI-N and, (Al-N)NRs are advantageous over Al-N nanosheets because it has small volume and free reactive edges giving more accessible to some doping [5] and chemical modification [6] which correspondingly resulting in higher susceptible structural defects [7]. Similarly, these structural defects also exist in Al-N nanostructure in which they can be deliberately introduced into the host Al-N lattice which correspondingly alter its physical properties by either irradiation or chemical treatments [8]. Furthermore, it is very well-known that dangling 


\begin{tabular}{|c|c|c|c|c|c|c|}
\hline \multirow{4}{*}{ Impact Factor: } & ISRA (India) & $=3.117$ & SIS (USA) & $=0.912$ & ICV (Poland) & $=6.630$ \\
\hline & ISI (Dubai, UAI & $=0.829$ & РИНЦ (Russia & $=0.156$ & PIF (India) & $=1.940$ \\
\hline & GIF (Australia) & $=0.564$ & ESJI (KZ) & $=8.716$ & IBI (India) & $=4.260$ \\
\hline & JIF & $=1.500$ & SJIF (Morocco & $=5.667$ & OAJI (USA) & $=0.350$ \\
\hline
\end{tabular}

bond (DB) defects around the vacancy sites or at the tips determine the electronic and magnetic properties of Al-N nanotubes [8].

\section{COMPUTATIONAL DETAILS DFT}

Our calculations are based on the use of DFT were performed using Gaussian 09 package[9] with the Becke- three parameter density functional with LeeYang-Parr correlation functional (PBE) [10] was used with the 6-31G(d,p) basis sets progressively in order to save computation time. Table 1 shows there is a difference between the HOMO and the LUMO energies of $\mathbf{P}(\mathbf{A l}-\mathbf{N})$-Sheet. The deduced values of ionization potential (IP), electron affinity (EA) are calculated by HOMO and LUMO energy, the IP, EA and Fermi energy $\left(\mathrm{E}_{\mathrm{F}}\right)$ for BN-Sheet. The energy gap $\left(E_{\mathrm{g}}\right)$ plays crucial role in the properties of a solid.

Table 1. The structural and electronic properties of pristine $P(A l-N)$ - Sheet.

\begin{tabular}{|l||l|}
\hline Property & P(Al-N) -Sheet \\
\hline E $_{\text {Tot }}$ & -3400.1595 \\
\hline $\mathbf{E}_{\mathbf{g}}$ & 0.6303 \\
\hline \hline $\mathbf{I P}=$ (-HOMO) & 6.9820 \\
\hline $\mathbf{E A = ( - L U M O )}$ & 6.3616 \\
\hline $\mathbf{E}_{\mathbf{F}}$ & -6.6718 \\
\hline
\end{tabular}

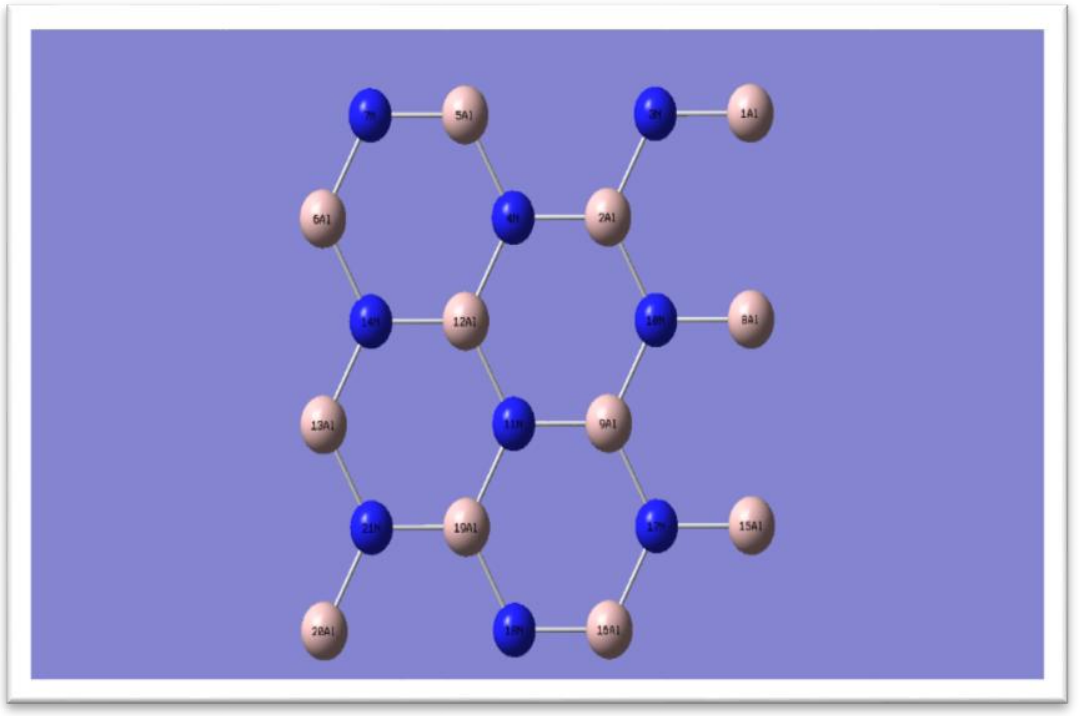

Fig. 1. Geometric structures of the $P(A l-N)$-Sheet

Figure 1 shows the structure of pristine aluminium nitride $\mathbf{P}(\mathrm{Al}-\mathrm{N})$-Sheet that is used in the present study, we can see from the figure that the structure of pristine $\mathbf{P}(\mathrm{Al}-\mathrm{N})$-Sheet contains 21 atoms (12 aluminium +9 nitrogen).

The optimized bond lengths of $\mathrm{B}-\mathrm{N}$ are $1.40 \AA$ for $\mathbf{P}(\mathrm{Al}-\mathrm{N})$-Sheet. These values are in agreement with other calculations for aluminium /nitrogen $\mathbf{P}(\mathrm{Al}-$ $\mathrm{N})$-hybrid[11]. On the other hand, the (PBE) /6$31 \mathrm{G}(\mathrm{d}, \mathrm{p})$ basis set is used for the geometry optimizations of the adsorption effect of $\mathrm{CO}$ and $\mathrm{NO}$ molecules on BN-Sheet . The (PBE) /6-31G (d,p) is a reliable and commonly used level of theory for nanotube structures [12,13]. We calculate the chemical potential or Fermi energy $\left(E_{F}\right)$ of the complexes, as given below,

$$
\mathbf{E}_{\mathrm{F}}=\mathrm{E}_{\text {HOMO }}+\mathrm{E}_{\text {LUMO }} / 2
$$

Where $\mathrm{E}_{\text {Hомо }}$ is the energy of the highest occupied molecular orbital and $\mathrm{E}_{\mathrm{LUMO}}$ is the energy of the lowest unoccupied molecular orbital. The energy gap in energy levels $\left(E_{g}\right)$ of a system is defined as $E_{g}$ $=\mathrm{E}_{\mathrm{LUMO}}-\mathrm{E}_{\text {HOMO }}$. The adsorption energy $\left(\mathrm{E}_{\mathrm{ads}}\right)$ is estimated using the following approximate expression:

$$
\mathbf{E}_{\text {ads }}=\mathbf{E}_{\text {COMPLEX }}-\left(\mathbf{E}_{\mathrm{BN}-\text { Sheet }}+\mathbf{E}_{\text {gas }}\right)
$$

Where $\mathrm{E}_{\text {complex }}$ corresponds to the $\mathrm{P}(\mathrm{Al}-\mathrm{N})-$ Sheet /gas complex in which the gas molecule has been adsorbed on the surface of $\mathrm{P}(\mathrm{Al}-\mathrm{N})-\mathrm{Sheet}, \mathrm{E}_{\mathrm{BN}-\text {-Sheet }}$ and $\mathrm{E}_{\mathrm{gas}}$ are the energy of the isolated $\mathrm{P}(\mathrm{Al}-\mathrm{N})-$ Sheet and gas molecule[14].

Figure 2 illustrated the density functional at 6$31 \mathrm{G}$ (d.p) basis set, to investigate the adsorption effect of gas molecules Cs effect on the electronic structure $\mathrm{P}(\mathrm{Al}-\mathrm{N})-$ Sheet. 


\begin{tabular}{|c|c|c|c|c|c|c|}
\hline \multirow{4}{*}{ Impact Factor: } & ISRA (India) & $=3.117$ & SIS (USA) & $=0.912$ & ICV (Poland) & $=6.630$ \\
\hline & ISI (Dubai, UAE & $=0.829$ & РИНЦ (Russia & $=0.156$ & PIF (India) & $=1.940$ \\
\hline & GIF (Australia) & $=0.564$ & ESJI (KZ) & $=8.716$ & IBI (India) & $=4.260$ \\
\hline & JIF & $=1.500$ & SJIF (Morocce & $=5.667$ & OAJI (USA) & $=0.350$ \\
\hline
\end{tabular}

\section{RESULTS AND DISCUSSION} Sheet

3.1 Electronic Structure of Pristine $\mathrm{P}(\mathrm{Al}-\mathrm{N})$ -

Table 1 listed the calculated structural and electronic properties of $\mathbf{P}(\mathrm{Al}-\mathrm{N})$-Sheet. The HOMO is the orbital that primarily acts as an electron donor and the LUMO is the orbital that mostly acts as the electron acceptor play a significant role for density of states (DOS) of $\mathbf{P}(\mathrm{Al}-\mathrm{N})-$ Sheet. The calculated electronic and structural properties of $\mathbf{P}(\mathrm{Al}-\mathrm{N})$ are listed in Table (3.1). The natural bond calculations were performed to conclude the total energy $\left(\mathrm{E}_{\mathrm{Tot}}\right)$, energy gap $\left(\mathrm{E}_{\mathrm{g}}\right)$, HOMO and LUMO energies and $\left(\mathrm{E}_{\mathrm{F}}\right)$. As is clear from the Table the Fermi energy is calculated from the $\mathrm{E}_{\text {Hомо }}$ and $\mathrm{E}_{\mathrm{LUMO}}\left(\mathrm{E}_{\mathrm{F}}=\left(\mathrm{E}_{\mathrm{HOMO}}+\right.\right.$ $\left.\mathrm{E}_{\mathrm{LUMO}}\right) / 2$ ) equal to $-6.671 \mathrm{eV}$, however, the $\mathbf{P}(\mathrm{Al}-\mathrm{N})$ is a semiconductor with $E_{g}=0.620 \mathrm{eV}$.

3.2 P(Al-N)-Sheet with Cs Gas Molecules Adsorption

In order to find the favorable adsorption configuration, a comprehensive study on the adsorption of gas molecules (Cs) on $\mathbf{P}(\mathrm{Al}-\mathrm{N})$-Sheet is placed at two different occupation sites: The top first site directly above the atom, top second site directly above the center ring of cs gas molecule, as shown in Figure 3. Its known that Cs is a non- disturbing and colorless gas, when it enters the body of human, Cs combines with blood haemoglobin that prohibit the union of oxygen and haemoglobin, leading to body tissue hypoxia and suffocation[15].

3.4 Adsorption of Gas CS on P(Al-N), B, P and C-Doped aluminium nitride (Al-N).

After adsorption of these gas we try to examine its effect on structural and electronic properties of $\mathrm{P}(\mathrm{Al}-\mathrm{N})$, B-doped aluminium nitride $\mathrm{P}$ doped aluminium nitride, $\mathrm{C}$-doped aluminium nitride and (adsorption center). In order to find the favourable adsorption configuration, a comprehensive study on the adsorption of gas molecules CS on molecules studies.

3.4.1 Electronic Properties of Adsorbed CS on $\mathrm{P}(\mathrm{Al}-\mathrm{N}), \mathrm{B}, \mathrm{P}$ and $\mathrm{C}$-Doped aluminium nitride (AlN).

The $\mathbf{P}(\mathrm{Al}-\mathrm{N})$, B-doped aluminium nitride $\mathrm{P}$ doped aluminium nitride, $\mathrm{C}$-doped aluminium nitride and (adsorption center) is considered a potential candidate of gases sensor, so the adsorption of CS molecules on various $\mathbf{P}(\mathrm{Al}-\mathrm{N})$, including (B-doped aluminium nitride $\mathrm{P}$-doped aluminium nitride, $\mathrm{C}$ doped aluminium nitride and (adsorption center), after relaxation of CS adsorbed on $\mathbf{P}(\mathrm{Al}-\mathrm{N})$, B-doped aluminium nitride $\mathrm{P}$-doped aluminium nitride, $\mathrm{C}$ doped aluminium nitride and (adsorption center) is shown in Fig. (3.6). Meanwhile, the bond lengths of, C-N, N-B and N-Al are 1.1.847 $\AA, 1.529 \AA$ and 1.818 $\AA$ respectively, are consistent with the other results [16], which basically decrease and increase of electrons decrease and increase in the elements [17]. from fig.(3.6) (a) the side view of gas molecules CS adsorption $\mathrm{Al}$ atom of $\mathbf{P}(\mathrm{Al}-\mathrm{N})$, on the distance (3.2 $\AA$ ), the fig (b) shows that the gas CS on the center ring of $\mathrm{P}(\mathrm{Al}-\mathrm{N})$, with $(3.2 \AA)$. The $\mathrm{CS}$ of the (B- doped $\mathbf{P}($ Al-N) on the distance $(3.2 \AA)$ it note that on the fig (c), fig(d) gas molecular on the center ring B- doped $\mathrm{P}(\mathrm{Al}-\mathrm{N})$, on the distance $(3.2 \AA)$, the CS of the Pdoped $\mathbf{P}(\mathrm{Al}-\mathrm{N})$, on the distance $(3.2 \AA)$ is observed that on the fig (e ), fig(f) gas molecular on the center ring $\mathrm{P}$ - doped $\mathrm{P}(\mathrm{Al}-\mathrm{N})$, for the distance $(3.2 \AA)$ the $\mathrm{CS}$ of the C- doped $\mathrm{P}(\mathrm{Al}-\mathrm{N})$ for the distance $(3.2 \AA)$ we see that on the fig $(\mathrm{g})$, fig(h) gas molecular on the center ring $\mathrm{C}$ - doped $\mathrm{P}(\mathrm{Al}-\mathrm{N})$, on the distance $(3.2 \AA)$.

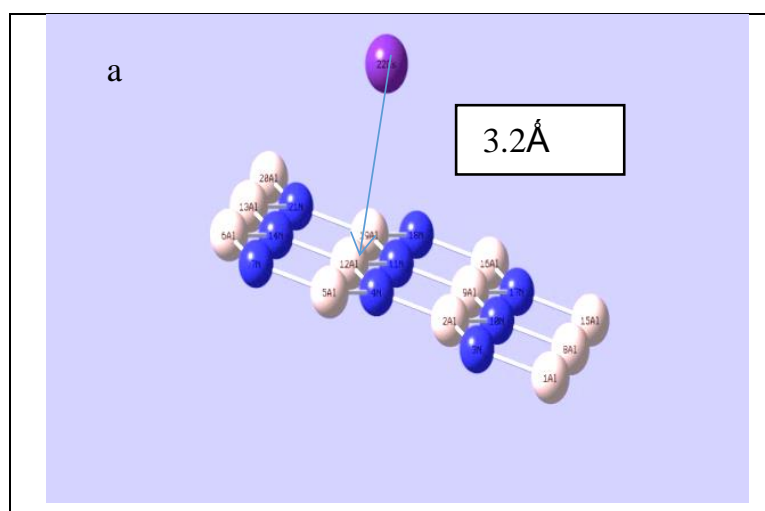

(Al-N)-CS

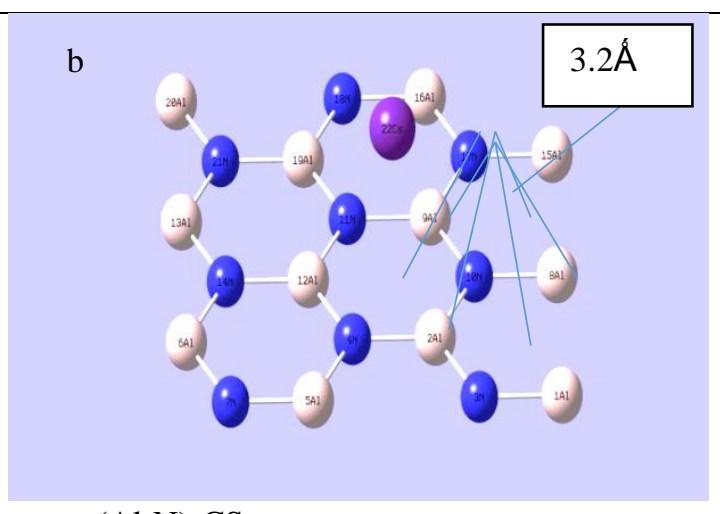

(Al-N)-CS center 


\begin{tabular}{|c|c|c|c|c|c|c|}
\hline \multirow{4}{*}{ Impact Factor: } & ISRA (India) & $=3.117$ & SIS (USA) & $=0.912$ & ICV (Poland) & $=6.630$ \\
\hline & ISI (Dubai, UAE & $=0.829$ & РИНЦ (Russia) & $=0.156$ & PIF (India) & $=1.940$ \\
\hline & GIF (Australia) & $=0.564$ & ESJI (KZ) & $=8.716$ & IBI (India) & $=4.260$ \\
\hline & JIF & $=1.500$ & SJIF (Morocco & $=5.667$ & OAJI (USA) & $=0.350$ \\
\hline
\end{tabular}

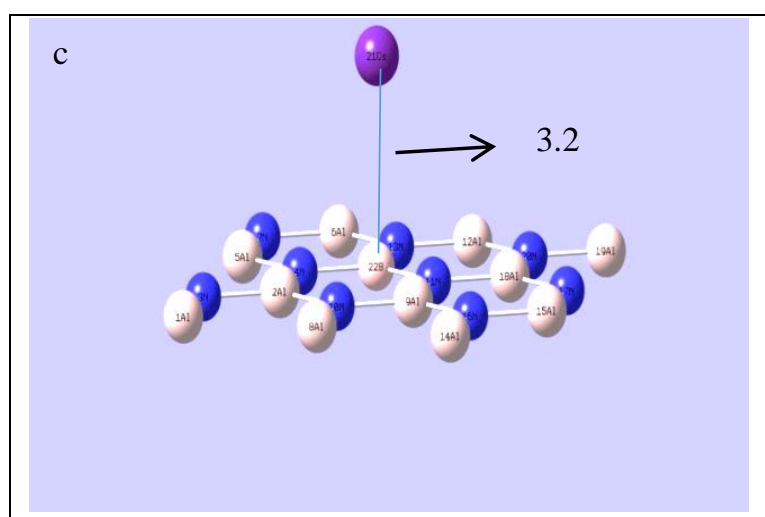

(Al-N-B)-CS
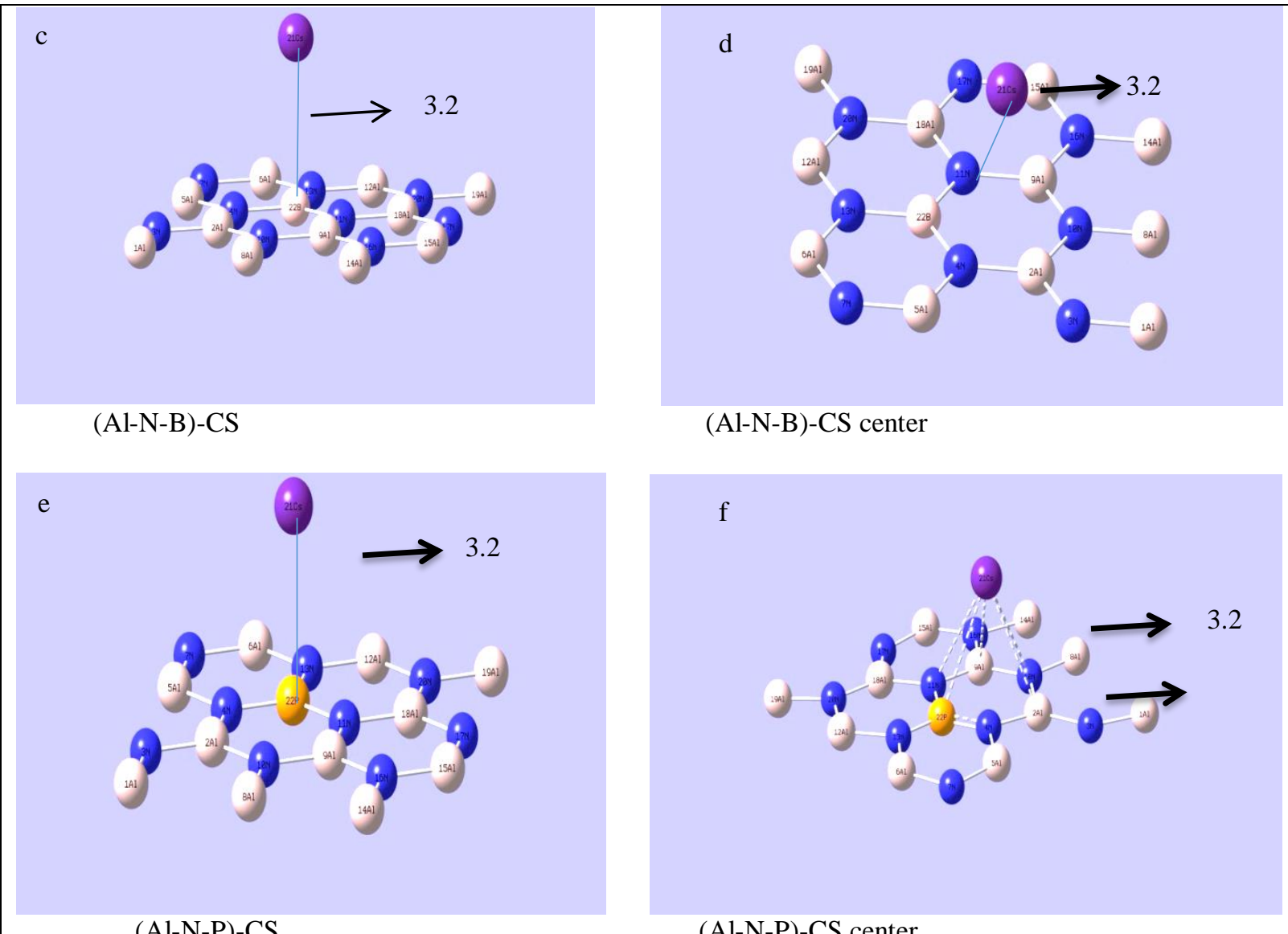

(Al-N-B)-CS center

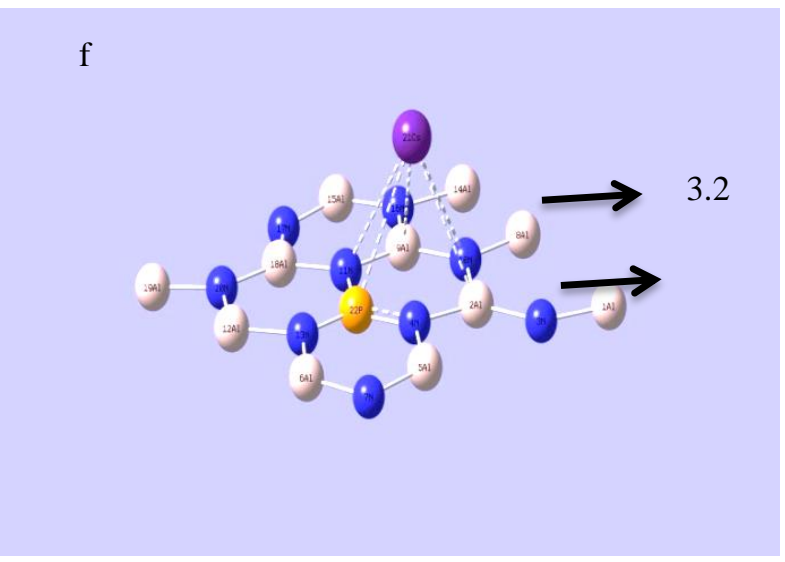

(Al-N-P)-CS center
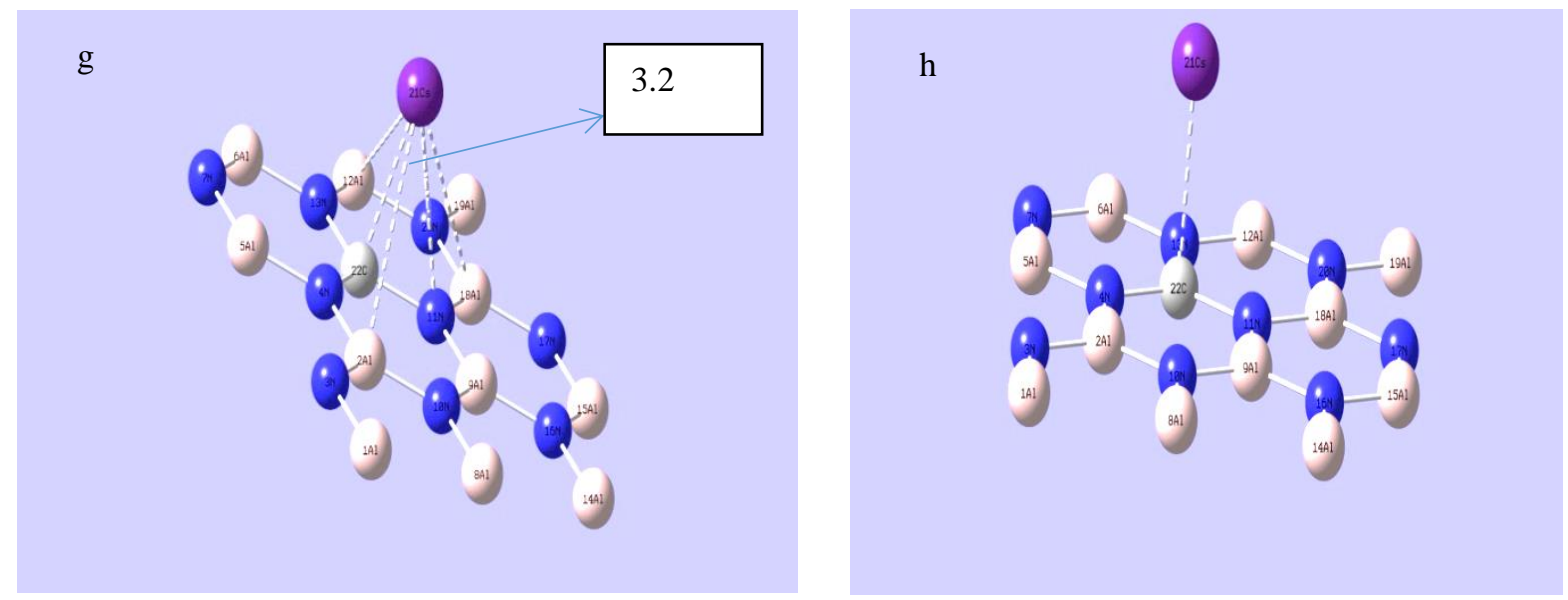

(Al-N-C)-CS

(Al-N-C)-CS center

Fig. 2. Structural model of Cs - P(Al-N) Sheet - Cs - P(Al-N) $)_{\text {center }}$ Sheet adsorptive system.

It can be noticed from Table (2.5), that $\mathrm{E}_{\mathrm{Tot}}$ for adsorption of CS on, $\mathbf{P}(\mathrm{Al}-\mathrm{N})$, B-doped $\mathbf{P}(\mathrm{Al}-\mathrm{N}), \mathrm{C}-$ doped $\mathbf{P}(\mathrm{Al}-\mathrm{N})$ and (adsorption center) are smaller than adsorbed P-doped $\mathbf{P}(\mathrm{Al}-\mathrm{N})$, this indicates that $\mathrm{E}_{\mathrm{Tot}}$ increases (in magnitude) with increasing the number of atoms while the $\mathrm{E}_{\mathrm{Tot}}$ for adsorption of $\mathrm{CS}$ on, B-doped $\mathbf{P}(\mathrm{Al}-\mathrm{N})$, C-doped $\mathbf{P}(\mathrm{Al}-\mathrm{N})$ and are smaller than adsorbed $\mathrm{P}(\mathrm{Al}-\mathrm{N})$ because that decreases (in magnitude) with decreasing the number of atoms. And adsorption energy ( $\left.E_{a d}\right)$ of CS on the $\mathbf{P}(\mathrm{Al}-\mathrm{N})$, Bdoped $\mathbf{P}(\mathrm{Al}-\mathrm{N})$, C-doped $\mathbf{P}(\mathrm{Al}-\mathrm{N})$ and (adsorption center) are $(0.976 \mathrm{eV}), 0.987 \mathrm{eV}),(2.07 \mathrm{eV})$ and $2.07 \mathrm{eV}),(10.9 \mathrm{Ev}),(12.67 \mathrm{eV}),(1.73 \mathrm{eV})$ and $(1.730$ $\mathrm{eV})$ respectively . $\mathrm{E}_{\mathrm{ad}}$ of a gas atom are found using 


\begin{tabular}{|c|c|c|c|c|c|c|}
\hline \multirow{4}{*}{ Impact Factor: } & ISRA (India) & $=3.117$ & SIS (USA) & $=0.912$ & ICV (Poland) & $=6.630$ \\
\hline & ISI (Dubai, UAE & $=0.829$ & РИНЦ (Russia & $=0.156$ & PIF (India) & $=1.940$ \\
\hline & GIF (Australia) & $=0.564$ & ESJI (KZ) & $=8.716$ & IBI (India) & $=4.260$ \\
\hline & JIF & $=1.500$ & SJIF (Morocce & $=5.667$ & OAJI (USA) & $=0.350$ \\
\hline
\end{tabular}

equation (2.67). However, the $\mathrm{E}_{\mathrm{g}}$ of $\mathrm{CS}$ oF the $\mathbf{P}(\mathrm{Al}-$ N), B-doped (Al-N), P-doped $\mathbf{P}($ Al-N) and C-doped $\mathbf{P}(\mathrm{Al}-\mathrm{N}) \quad$ are $(1.0176 \mathrm{eV}),(0.813 \mathrm{eV}), \quad(0.511 \mathrm{eV})$ and $(1.384 \mathrm{eV})$ respectively. While $\left(\mathrm{E}_{\mathrm{g}}\right)$ of $\mathrm{CS}$ on the center ring of the are $\mathbf{P}(\mathrm{Al}-\mathrm{N})$, B-doped $\mathbf{P}(\mathrm{Al}-\mathrm{N})$, $\mathrm{P}-$ doped $\mathbf{P}(\mathrm{Al}-\mathrm{N})$ and $\mathrm{C}$-doped $\mathbf{P}(\mathrm{Al}-\mathrm{N}) \quad(0.873 \mathrm{eV})$, $(0.552 \mathrm{eV}),(1.384 \mathrm{eV})$ and $(1.634 \mathrm{eV})$ respectively. $\mathrm{E}_{\mathrm{g}}$ of a gas atom are found using equation (2.67). While the $\mathrm{E}_{\mathrm{g}}$ for adsorption of CS on $\mathbf{P}(\mathrm{Al}-\mathrm{N})$, B-doped $\mathbf{P}(\mathrm{Al}-$ $\mathrm{N})$, P-doped $\mathbf{P}(\mathrm{Al}-\mathrm{N})$ are smaller than those of Cdoped $\mathbf{P}(\mathrm{Al}-\mathrm{N})$ respectively, which indicates that the $\mathrm{E}_{\mathrm{g}}$ decreases with the adsorption of $\mathrm{CS}$ on $\mathbf{P}(\mathrm{Al}-\mathrm{N})$, Bdoped $\mathbf{P}(\mathrm{Al}-\mathrm{N})$, P-doped $\mathbf{P}(\mathrm{Al}-\mathrm{N})$. One can see from the overall results that are displayed in Table (3). The $\mathrm{E}_{\mathrm{ad}}$ of, B-doped $\mathbf{P}(\mathrm{AlN})$, P-doped -(Al-N) and Cdoped $\mathbf{P}(\mathrm{Al}-\mathrm{N}$ ) (on atom and center ring) is larger than $1 \mathrm{eV}$, corresponding to strong chemisorption [18]. The $\mathrm{E}_{\mathrm{ad}} \mathbf{P}(\mathrm{Al}-\mathrm{N})$ (on atoms and center ring) are smaller than $1 \mathrm{eV}$, corresponding to weak physisorption [19]. The $\mathrm{E}_{\mathrm{ad}}$ for $\mathbf{P}(\mathrm{Al}-\mathrm{N})$ are: $(0.976$
$\mathrm{eV})$ and $(0.987 \mathrm{eV})$ are in agreement with the previous results [20]. In general, the $\mathrm{E}_{\mathrm{ad}}$ in the results indicates that $\mathrm{B}$-doped $\mathrm{P}(\mathrm{Al}-\mathrm{N}), \mathrm{P}$-doped $\mathrm{P}(\mathrm{Al}-\mathrm{N})$. Cdoped $\mathrm{P}(\mathrm{Al}-\mathrm{N})$. is strongly reactive to molecule $\mathrm{CS}$, the Ead is $(2.07 \mathrm{eV})$ and $(2.07 \mathrm{eV})$ center ring, $(10.9 \mathrm{eV}),(12,67 \mathrm{eV})$ center ring, $(1.730 \mathrm{eV}),(1.730 \mathrm{eV})$ center ring, corresponding to a strong chemisorption. Therefore, due to gas slow desorption from B-doped $\mathrm{P}(\mathrm{Al}-\mathrm{N})$, P-doped $\mathrm{P}(\mathrm{Al}-\mathrm{N})$ and $\mathrm{C}$-doped $\mathrm{P}(\mathrm{Al}-\mathrm{N})$ is not suitable as a sensor of CS. Nevertheless, this molculars could catalyst or activate this adsorbate due to the strong interaction, suggesting the possibility of B-doped P(Al-N), P-doped P(Al-N) and C-doped $\mathrm{P}(\mathrm{Al}-\mathrm{N})$ as a catalyst. The results Ead for $\mathrm{P}(\mathrm{Al}-\mathrm{N})$, Bdoped $\mathrm{P}(\mathrm{Al}-\mathrm{N})$ and $\mathrm{C}$-doped are $\mathrm{P}(\mathrm{Al}-\mathrm{N})$ consistent with those reported in other studies [15]. Thus, P(Al$\mathrm{N}$ ), can be used to detect CS since the adsorptiondesorption equilibrium of $\mathrm{CS}$, the $\mathrm{P}(\mathrm{Al}-\mathrm{N})$, are easily built.

Table 2. Structural and electronic properties of adsorption of CS molecule gas on P(AIN), B, P and C-Doped aluminium nitride (Al-N).

\begin{tabular}{|c|c|c|c|c|c|c|c|c|}
\hline $\begin{array}{l}\text { Property } \\
(\mathrm{eV})\end{array}$ & $\mathrm{a}$ & $\begin{array}{l}\mathrm{b} \\
\text { Centre }\end{array}$ & $\mathrm{c}$ & $\begin{array}{l}\mathrm{d} \\
\text { Centre }\end{array}$ & $\mathrm{e}$ & $\begin{array}{l}\mathrm{f} \\
\text { Centre }\end{array}$ & $\mathrm{g}$ & $\begin{array}{l}\mathrm{h} \\
\text { Centre }\end{array}$ \\
\hline ETot (au) $_{\text {(au }}$ & 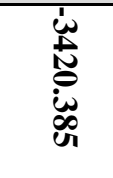 & 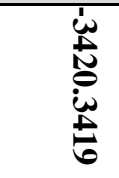 & 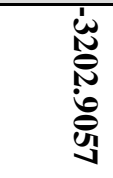 & 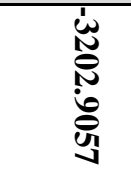 & 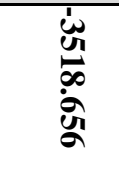 & 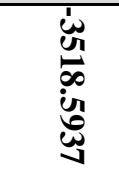 & 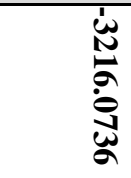 & 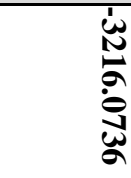 \\
\hline Eads & 0.976 & 0.987 & 2.07 & 2.07 & 10.9 & 12.67 & 1.730 & 1.730 \\
\hline $\mathrm{Eg}_{\mathrm{g}}$ & 1.017 & 0.873 & 0.813 & 0.813 & 0.511 & 0.552 & 1.384 & 1.384 \\
\hline $\mathrm{E}_{\text {HOMO }}$ & -3.920 & -3.953 & -4.103 & -4.103 & -3.833 & -3.923 & -4.326 & -4.323 \\
\hline $\mathrm{E}_{\text {LUMO }}$ ) & -2.903 & -3.080 & -3.289 & -3.289 & -3.322 & -3.371 & -2.938 & -2.938 \\
\hline$E_{F}$ & 3.412 & -3.516 & -5.520 & 3.696 & -3.578 & -3.647 & -3.631 & -3.631 \\
\hline $\mathrm{EA}=-\mathrm{E}_{\text {LUMO }}$ & 4.157 & 4.090 & 4.969 & 5.175 & 4.336 & 4.495 & 4.406 & 4.455 \\
\hline $\mathrm{E}_{\mathrm{F}}$ & -5.275 & -5.211 & -5.520 & -5.583 & -5.257 & -5.498 & -5.286 & -5.272 \\
\hline
\end{tabular}

\section{CONCLUSIONS}

The bond lengths of optimized structure for adsorbed system decrease with increasing of number of electrons in the elements. The calculated $\mathrm{E}_{\mathrm{Tot}}$ for all systems increases (in magnitude) with increasing the number of atoms. There is no distortion in the planar structure of $\mathbf{P}(\mathrm{Al}-\mathrm{N})$ sheet in the case of doping Bdoped $\mathbf{P}(\mathrm{Al}-\mathrm{N})$, P-doped $\mathbf{P}(\mathrm{Al}-\mathrm{N})$. C-doped $\mathbf{P}(\mathrm{Al}-$ $\mathrm{N})$ The adsorption of gas molecules on $\mathbf{P}(\mathrm{Al}-\mathrm{N})$. Pristine (Al-N) sheet can be used as a good sensor for $\mathrm{CS}$, and not suitable for usage as a gas sensor for Bdoped $\mathbf{P}(\mathrm{AlN})$, P-doped $\mathbf{P}(\mathrm{Al}-\mathrm{N})$. C-doped $\mathbf{P}(\mathrm{Al}-\mathrm{N})$. 


\begin{tabular}{llllll} 
& ISRA (India) $=\mathbf{3 . 1 1 7}$ & SIS (USA) $=\mathbf{0 . 9 1 2}$ & ICV (Poland) & $\mathbf{= 6 . 6 3 0}$ \\
Impact Factor: & ISI (Dubai, UAE) $=\mathbf{0 . 8 2 9}$ & PUHЦ (Russia) $=\mathbf{0 . 1 5 6}$ & PIF (India) & $=\mathbf{1 . 9 4 0}$ \\
& GIF (Australia) $=\mathbf{0 . 5 6 4}$ & ESJI (KZ) & $\mathbf{8 . 7 1 6}$ & IBI (India) & $=\mathbf{4 . 2 6 0}$ \\
& JIF & $\mathbf{1 . 5 0 0}$ & SJIF (Morocco) $=\mathbf{5 . 6 6 7}$ & OAJI (USA) & $\mathbf{0 . 3 5 0}$ \\
\hline
\end{tabular}

\section{References:}

1. Novoselov, K. S., et al. (2005). Proc. Natl. Acad. Sci. U.S.A., 102, 10451-10453.

2. Geim, A. K., \& Novoselov, K. S. (2007). Nat. Mater., 6, 183-191.

3. Blasé, X., Rubio, A., Louie, S. G., \& Cohen, M. L. (1995). Phys. ReV. B, 51, 6868-6875.

4. Watanabe, K., Taniguchi, T., \& Kanda, H. (2004). Nat. Mater., 3, 404-409.

5. Novoselov, K. S., et al. (2004). Science 306, 666.

6. Pease, R. S. (1952). An x-ray study of boron nitride. Acta Crystallogr, 5, 356-361.

7. Geick, R., Perry, C. H., \& Rupprecht, G. (1966). Normal modes in hexagonal boron nitride. Phys. Rev., 146, 543-547.

8. Rumyantsev, S. L. (2001). Properties of Advanced Semiconductor Materials GaN, AlN, $\mathrm{InN}, \mathrm{BN}, \mathrm{SiC}, \mathrm{SiGe}$. Edited by M. E. Levinshtein, S. L. Rumyantsev, and M. S. Shur John Wiley and Sons (Eds.). (pp.67-92). New York.

9. Rubio, A., Corkill, J. L., \& Cohen, M. L. (1994). Theory of graphitic boronnitride nanotubes, Phys. Rev. B, 49, 5081-5084.

10. Frisch, M. J., et al. (2009). Gaussian 09, revision A. 02 Gaussian, Inc., Wallingford CT.

11. Seminaro, J. M., \& Politzer, P. (1995). Modren Density Functional Theory: A Tool for Chemistry, University of New Orleans, USA.
12. Drissi, L. B., Saidi, E. H., Bousmina, M., \& Fassi-Fehri, O. (2012). J. Phys.: Condens. Matter 24, 485-502.

13. Gan, L., \& Zhao, J. (2009). Physica E 41, 1249.

14. Ahmadi, A., Beheshtian, J., \& Kamfiroozi, M. (2012). Journal Molecular Model 18, 17-29.

15. Wendt, M., \& Weinhold, F. (2001). NBO View 1.0. Theoretical Chemistry Institute, University of Wisconsin, Madison.

16. Zhang, X., Dai, Z., Wei, L., Liang, N., \& Wu, X. (2013). Sensors 13, 151-159.

17. Imani, K., Jafari, G., \& Abolhasani, M. R. (2012). ISRN Condensed Matter Physics 2012, 5, Article ID 368634

18. Jiang, Y., Yang, S., Li, S., Liu, W., \& Zhao, Y. (2015). Journal of Nanomaterials, 7 (2015), Article ID 504103.

19. Feng, J., Liu, Y., Wang, H., Zhao, J., Cai, Q., \& Wang, X. (2014). Computational Materials Science, 87, 218.

20. Huang, B., et al. (2008). J. Phys. Chem. C 112, 134-142.

21. Pashangpour, M. (2010) International Conference on Nanotechnology and Biosensors IPCBEE, IACSIT Press, Singapore, Vol. 2. 